\title{
BMPS AND LIVER: MORE QUESTIONS THAN ANSWERS
}

Blanca Herrera $^{1^{*}}$, Aránzazu Sánchez ${ }^{1}$, Isabel Fabregat ${ }^{2}$

1. Dep. Bioquímica y Biología Molecular II, Facultad de Farmacia, Universidad Complutense, Madrid, Spain.

2. Bellvitge Biomedical Research Institute (IDIBELL) and University of Barcelona (UB). L'Hospitalet, Barcelona, Spain.

* To whom correspondence should be addressed:

Dr. B. Herrera. Dep. Bioquímica y Biología Molecular II, Facultad de Farmacia, Universidad Complutense, Plaza Ramón y Cajal S/N, 28040-Madrid, Spain. Phone \#: 34-913941854. Fax \#: 34 913941779.

bm.herrera@farm.ucm.es

Keywords: BMP, liver, signaling, fibrosis, hepatocellular carcinoma, development, iron homeostasis.

Short running title: BMPS in liver 


\begin{abstract}
Bone morphogenetic proteins (BMPs) belong to the TGF- $\beta$ superfamily and were first discovered as potent bone homeostasis regulators for their ability to induce endochondral bone formation, ectopic bone formation and fracture repair. A preeminent role of BMP signaling in developmental control of cell type specification, differentiation and organogenesis is also well established.

More recently, a role for BMPs in adult tissue homeostasis have started being revealed. Thus, new studies show that BMPs regulate many cellular processes such as proliferation, apoptosis, differentiation and migration in many tissues and organs. As a consequence, dysregulation of BMP activity can have pathological consequences, and there is mounting evidence for the involvement of BMPs in different human diseases. In this review, we have focused on summarizing the present knowledge on the relevance of BMPs in liver physiology and pathophysiology, from the well-recognized role in liver development to the emerging contribution to the function and dysfunction of the adult liver. While no doubts seem to rise about the regulatory activities of BMPs on metabolic pathways in the liver, potential pro- and antifibrogenic and tumorigenic actions will likely be a matter of debate during coming years. Collectively, the work here presented provides the basis to consider BMPs as potential targets of intervention in liver diseases.
\end{abstract}




\section{Signaling by BMPs}

\subsection{Ligands secretion and activation}

BMPs (Bone morphogenetic proteins) are a large subfamily of the TGF-_ superfamily, comprising more than 20 members. They are synthesized as large precursor proteins comprised by $\mathrm{N}$-terminal signal peptide, which directs the protein to the secretory pathway; a prodomain required for proper folding and the Cterminal mature peptide. The prodomain is usually cleaved by proteases within the Golgi network to generate the mature active protein. In some cases (i.e., BMP9 and GDF8) the prodomain remains attached to the mature protein even after secretion, a phenomenon whose consequences are not yet known. Active BMPs are disulfide-linked homo- or heterodimers. An increased activity of BMP heterodimers both in vitro and in vivo and/or novel properties have been reported [1-3]. Both the cleavage of the prodomain, which may interfere with the binding to the receptor, and the formation of homo- or heterodimers constitute two levels of BMP signaling modulation [4].

\subsection{Receptors and co-receptors}

BMPs bind to a heterotetrameric complex transmembrane receptor comprised by type I and type II serine threonine kinase receptors. Both types of receptors contain an N-terminal extracellular ligand binding domain, a transmembrane region and an intracellular kinase domain. Upon ligand binding, the type II receptor constitutively active serine-threonine kinase phosphorylates type I receptor within a glycine-serine rich region (GS box), event that is required for the activation of the type I receptor. Transphosphorylation of GS box is required for the activation of the type I receptor. Four different type I receptors, also named activin receptor like kinase (ALK) have been implicated in BMP signaling: ALK1, ALK2, ALK3 (BMPRIA) and ALK6 (BMPR-IB). It is also well established that BMPs bind to three distinct type II receptors, namely BMP type II receptor (BMPRII), activin type II receptor A (ActRIIA) and activin type II receptor B (ActRIIB) [5, 6]. Despite the fact that different type I and type II receptors present high level of homology, they are non redundant. Actually, the combinatorial interactions of the different type I and type II receptors 
in functional complexes allow for diversity and selectivity in ligand binding as well as intracellular signaling, which is ultimately responsible for the highly specific functions exerted by the different receptors [7]. In contrast to TGF- $\beta 1$ which binds with high affinity to type II receptors, most BMP ligands bind efficiently to type I receptor. When both type I and type II receptors are present, the binding affinity increases dramatically. It has been suggested that a small fraction of type II and type I receptors are present in the cell surface as preformed complexes which may play a role in Smad independent pathways $[5,8,9]$. In addition to type I and type II BMP receptors, co-receptors have been shown to participate in the BMP response. One of these is Endoglin (Eng), a transmembrane glycoprotein that is expressed mainly in endothelial cells. Eng is required for TGF- $\beta$ transduction via type I receptor ALK1, modulating the balance in ALK1/ALK5 signaling in response to TGF- $\beta$ in endothelial cells [10-12]. It has been recently shown that it also participates in BMP9 signaling [13, 14]. Betaglycan is a transmembrane proteoglycan that binds and presents TGF- $\beta$ and BMP ligands to the type II and type I receptors, respectively, and modulates BMP mediated signaling [15-19]. Other co-receptors that enhance BMP signaling are members of the Repulsive Guidance Molecule family (RGM). RGM molecules modify specific BMP ligands binding affinity for the BMP type II receptor, thus cells expressing RGM members become more responsive to low concentrations of specific BMPs [20]. RGM family members and activities are: i) RGMa (or RGM) that enhances BMP2 and BMP4 but not TGF- $\beta$ or BMP7 signaling, whilst the effect on other BMP ligands have not been analyzed yet; ii) RGMb (or DRAGON) that enhances BMP signaling, with a greater effect on BMP2 and BMP4, little effect on BMP5, BMP6 and BMP7 and no effect on BMP9; iii) RGMc (or hemojuvelin) that has a major role in iron metabolism and is characterized by a strong binding affinity for BMP6. RGMc presents less affinity for BMP2, BMP4 and BMP5 and little or no effect for BMP7 and BMP9; iv) RGMd, only expressed in fish [20].

\subsection{Extracellular regulators.}

Other important modulators of the BMP signaling are the extracellular regulators, soluble secreted proteins that antagonize or potentiate BMP signaling with a major role in development. The network formed by Chordin / Tolloid metalloproteinase / Sizzled / Twisted grastrulation / ONT-1/ Crossveinless-2 controls dorsal-ventral development, creating a dynamic morphogenetic field of BMP activity. Cerberus / Gremlin / 
Dan family members are BMP inhibitors that also modulate other signaling pathways such as Nodal or Wnt. Another extracellular regulators of the BMP signaling are Noggin, follistatin, and the recently discovered Brorin and Brorin like, also known as tsukushi [21-23]. In adult tissues, reactivation of quiescent BMP extracellular regulators expression can contribute to some pathologies, such as cancer, although the involvement of these molecules in liver diseases has not yet been fully characterized.

\subsection{Activation of canonical and non-canonical pathways}

Upon ligand binding, receptor complexes activate the canonical Smad pathway and several Smad independent signaling pathways (Figure 1). There are three different types of Smad: receptor regulated Smads or R-Smads, Smad1, Smad2, Smad3, Smad5, Smad8; common mediator Smad or co-Smad, Smad4; and inhibitory Smads, Smad6 and 7. Once activated, type I receptor recruits and phosphorylates R-Smads at the C-terminus. Type I receptor mediated phosphorylation relieves R-Smads from the autoinhibitory structure they adopt when they are unphosphorylated. Upon the new conformation, the nuclear import signal is exposed, the affinity for Smad4 increases and R-Smads-Smad4 complexes are formed and accumulate in the nucleus [4]. ALK1, ALK2, ALK3 and ALK6 specifically phosphorylate Smad1, Smad5 and Smad8, which enables complex formation with the co-Smad, Smad4.

Once R-Smads have formed a complex with Smad4, they translocate to the nucleus to regulate gene transcription. Smad1/5 bind to G-C rich sequences such as GCCGnCGC motif found in the Smad6 promoter region [24] or (T)GGCGCC motif found in Bambi or hepcidin, among others [25, 26]. Smad1/5 also bind to Id1 gene promoter containing both SBE (Smad binding element) and GC rich box motifs [27]. In order to exert their transcriptional activity, Smad1/5 recruit DNA binding partners that include transcription factors such as Runx, among others, transcriptional co-activators (p300, CBP and others) and transcriptional co-repressors (Ski, SnoN) [5, 6]. As Smads DNA binding partners play critical roles in mediating BMP specific responses and the number of Smad1/5 DNA binding proteins identified is limited, it would be of great interest to expand the current knowledge about Smad1/5 transcriptional partners in different cell types. 
BMPs have been described to activate other signaling pathways independent of Smad activation, depending on the cell type and also the status of the target cell. In this line, p38, ERK, and JNK MAPKs, as well as PI3K, NF-kB, and Wnt pathways, have been shown to be activated by BMPs and mediate BMPs-induced biological activities in a variety of cell types [28-33] [33-38]. BMPs are able to trigger different signaling pathways simultaneously in some conditions $[39,40]$ but also to selectively induce the canonical and noncanonical pathways in the same cell type, driving different biological effects. An example that illustrates this BMP signaling versatility is the BMP mediated retina regeneration. In this process, BMP orchestrates the response of stem cells: in a first step, BMP drives an increase in cellular proliferation mediated by Smad. In a second step, BMP induces apoptosis by a Smad independent pathway involving p38MAPK and AKT activation [41].

It has been known for years that BMPs can drive LIMK activation. In a basal state, BMPRII binds and inhibits LIMK1 and upon ligand binding, LIMK1 is relieved and able to phosphorylate its substrates, such as cofilin, and thereby able to regulate actin cytoskeleton [42]. Furthermore, BMPs have been shown to regulate Rho GTPases that may have an impact in cell polarity and migration [35, 43].

In recent years, evidence has accumulated that microRNAs (miRNA) may mediate BMP effects. miRNAs are short molecules that enable cells to modulate protein expression by targeting mRNA, usually resulting in the silencing of target RNA [44, 45]. In a model of somatic cell reprogramming to generate multipotent stem cells, exogenous and autocrine BMP signaling induces the expression of the miR205 and the miR200 family members. Expression of these miRNAs is required for the mesenchymal to epithelial transition, a key component of the initiation phase of reprogramming [46]. On this regard, it has been reported that BMP4 regulates the expression level of miR210 and this effect contributes to osteoblastic differentiation [47]. miR199a(*) is an early responsive target of BMP2 during chondrogenesis [48] and several miRNAs are regulated in the BMP2 induced osteogenesis [49]. Also, BMP2 and BMP4 driven myocardial differentiation is dependent on miRNA17-92 [50]. Dr. Hata's group has added some interesting findings about BMP mediated miRNA modulation. They have reported not only that Smads promote the expression of a set of miRNAs but also that Smads regulate miRNA processing, elegantly demonstrating that Smads control miRNA expression at the post-transcriptional level [51-53]. 


\section{BMPs in liver physiology}

\subsection{BMP signaling in the liver}

In studies performed by RT-PCR in whole human liver RNA, Xia et al. found the expression of ALK2, ALK3 and ALK6 TGF- $\beta$ type I receptors [54]. In agreement, ALK3 protein expression has also been shown in regenerating mouse liver [5]. Additionally, Xia and coworkers found that ActRIIA is the predominant BMP type II receptor in human liver while they could not detect BMPRII expression. However, Arndt et al. found BMPRII expression in primary mouse hepatocytes [55]. Interestingly, BMPRII is expressed during liver organogenesis [56] and it can also be found in liver tumor cell lines, such as HepG2 cells, which also express ActRIIB [54, 57]. A more systematic analysis of the BMP receptors expression in different populations of liver cells and in HCC (hepatocellular carcinoma) cells is required to fully understand the significance of the BMP receptors differential expression in liver pathophysiology. BMP9 has been shown to be expressed in human liver, being its expression specially relevant in hepatocytes and intrahepatic biliary epithelial cells [58] .

It is well established that BMPs elicit a Smad response in hepatocytes and stellate cells [59] but little is known about the response to BMPs of other liver cell types. In this respect, the only evidence of BMP activity in liver endothelial cells and in Kupffer cells comes from Miller et al., who demonstrated that BMP9 binds to both types of rat isolated liver cells. What are the signaling pathways or the biological effect triggered by BMP9 binding on those cell types remain to be determined [60]. As to the possible involvement of non-canonical pathways in the BMP function in liver, it is an almost unexplored research field.

\subsection{Role of BMPs in liver development}

We are now beginning to understand the fundamental processes that control the liver development. Indeed, many of the pathways involved in the different stages of hepatic development have been identified and among them, BMP signaling has been proposed to have a crucial role in the early liver specification.

Liver arises from the ventral foregut endoderm, which is a multipotent tissue that also gives raise to other organs, such as lung, pancreas and thyroid. The different regions of the gut are patterned by signals from 
the mesoderm [61]. In a first step, suppression of mesodermal Wnt and FGF4 signaling is necessary for liver induction. Retinoic acid released from paraxial mesoderm cells defines anteroposterior position for the developing liver [61]. In a next step, cells in ventral foregut received FGF signals from cardiac mesoderm [62] and BMPs from septum transversum [63] that enables them to induce a liver program and suppress the pancreas program. These elegant studies from Dr. Zaret's lab suggest that in addition to a role for BMPs in the induction of liver gene expression, BMPs appear to be required during liver bud morphogenesis. It has been proposed that the main BMP contributor to the hepatic specification is BMP4. BMP4 was found to be expressed in the septum transversum at the time of hepatic specification and BMP4 null mice showed a delay in liver bud formation [63]. Nevertheless the contribution of other BMPs can not be ruled out. Supporting this notion, not only BMP4, but also BMP5 and BMP7, are expressed in cardiac mesoderm and/or septum transversum mesenchyme [64-67]. Initial induction of hepatic gene expression in the liver bud was only delayed, but not abolished, in the BMP4 null mice, suggesting that other BMP ligands could compensate for the absence of BMP4 [63]. Furthermore, in explant assays of foregut endoderm, BMP2 and BMP7, in addition to BMP4, increased the albumin mRNA expression levels, with a minor effect of BMP9 [63].

Little is known about the signaling pathways involved in the liver specification triggered by BMPs. The nature of the BMP receptors implicated in this process is not known but endoderm express at least BMPRIA, BMPRII and ActRIIA [68, 69]. It is well established that BMP signaling contributes to the regulation of the expression of transcription factors implicated in liver specification, such as Gata4 [63]. Further studies are necessary to clarify the possible role of BMP signaling in the control of other transcription factors involved at this stage of liver development, like FoxA (Forkhead box A) and Gata6.

All these events conclude in the specification of hepatoblasts, cells that express serum protein genes specific of hepatocytes, such as albumin, alpha-fetoprotein, and transthyretin, and are bipotential, giving rise to hepatocytes and cholangiocytes. Hepatoblasts delaminate from the foregut and invade the septum transversum and organize to generate the hepatic architecture. Liver organogenesis is a very complex process that involves differentiation and expansion of different cell populations, deposition of extracellular matrix, organization of hepatic vasculature and biliary tract. Homeobox transcription factors genes, like Prox1, Hnf6 and OC2, as well as other transcription factors, namely Xbp1 (Xenopus X-box binding protein 
1), Foxm1b, AP1 and Hex, have been implicated in these processes[70-72]. Hex is of particular interest as data in the literature have shown a role for BMP signaling in controlling its expression. In fact, analysis of the Hex promoter has revealed the presence of a BMP responsive element indicating that the BMP mediated Hex regulation is Smad dependent [73]. Additionally, expression of hhex and prox1 during zebra fish liver development is controlled by BMPs [74]; and some data point at Xbp1 as target for modulation of BMP activity in xenopus embryos [75]. The role of BMP signaling in mammal liver development at this stage of liver organogenesis is not yet fully understood.

Biliary and hepatocyte morphogenesis modulation is controlled by Smad signaling, as recently shown by Rogler et al (2009). Expression levels of Smad3, 4 and 5 are controlled by miRNA Mir23b cluster. High expression levels of Mir23b cluster in the hepatoblast drive Smad targeting and allows for hepatocyte fate. Low levels of Mir23b are responsible for Smad stabilization and promotion of cholangiocyte differentiation and bile duct formation. In addition to these evidences, expression of chordin, a soluble antagonist of BMP, has been shown to be expressed in the liver further supporting the notion of a role for BMPs in hepatoblast differentiation $[76,77]$.

All this accumulated knowledge on the signals and mechanisms that regulate liver embryonic development has been very useful for the establishment of more efficient and reproducible in vitro differentiation protocols to generate hepatocyte-like cells out of embryonic stem (ES) cells. A fundamental role for BMP signaling in this process has also been found. ES cells are pluripotent cells derived from the inner cell mass of blastocyst and can be isolated, cultured and differentiated into hepatic progenitor cells with hepatocyte and cholangiocyte differentiation potential. Demonstration of the combined effect of BMPs and FGFs in inducing mouse and human ES cells differentiation into hepatocytes has been provided. Thus, several laboratories have shown that inhibiting BMPs with noggin blocks induction of liver specific genes in ES cells proving that endogenous BMPs are needed for induction of hepatocyte differentiation [78, 79]. Furthermore, BMP4 has been reported to be necessary to induce definitive endoderm from mouse and human embryonic stem cells in vitro [80]. BMP2 appears to have a similar effect to that of BMP4 [81, 82], whereas BMP7 has been shown to potentiate mesoderm differentiation and inhibit definitive endoderm differentiation $[79,83]$. Oval cells are adult liver stem cells that resemble embryonic hepatoblasts as they express both hepatocyte and bile duct markers. The activation of oval cells in the adult in response to injury 
and the signals and pathways controlling this phenomenon as well as other processes in oval cell biology are not yet fully understood [84, 85]. Given the multifunctional role assigned to BMP signaling during early liver development, including hepatic specification and liver morphogenesis, a potential role for BMP in oval cell activation, expansion and differentiation should be considered.

\subsection{Role of BMPs in adult liver homeostasis}

\subsubsection{Iron metabolism}

Recent advances in the field of iron metabolism have led to a better understanding of the pathways and tissues involved in this process, revealing the key role of the BMPs and the liver (Figure 2). The major regulator of iron metabolism is hepcidin, a protein mainly expressed by hepatocytes that controls the iron entry into the plasma, decreasing it. Mutations in hepcidin genes are cause of Juvenile hemochromatosis, an autosomal recessive disease characterized by iron overload [86]. Hepcidin regulates iron metabolism by regulating ferroportin. Ferroportin is an iron exporter mainly expressed in duodenal enterocytes, where it controls the export of dietary iron into the circulation. It is also expressed in macrophages and hepatocytes, where it controls the iron release from its body stores. Hepcidin binds to and facilitates ferroportin internalization and degradation, therefore, hepcidin decreases iron plasma concentration [87-89]. The observation that mutations in hfe2, the gene that encodes for hemojuvelin, also known as RGMc, cause juvenile hemochromatosis opened a new line of iron metabolism research [90]. Shortly after that, Dr. Lin's group identified hemojuveline (HJV) as a co-receptor for BMP signaling and showed that BMP signaling positively regulates hepcidin expression [91]. Since then, many papers have provided increasing evidence supporting a central role for BMP6 in the control of iron homeostasis. The main findings of some of these studies are briefly summarized in here (for a more extensive review see [92, 93]]: i) HJV knock out mouse presents impaired BMP signaling [91]; ii) HJV knock out mice livers have low phospho Smad1,5, 8 activity [91], iii) HJV binds directly to BMP ligands, mainly BMP2, BMP4 and BMP6, being BMP6 the ligand with higher affinity, as demonstrated by both in vitro and ex vivo experiments [55, 94]; iv) BMP

ligands enhance hepcidin expression at the transcriptional level as hepcidin promoter have two BMP responsive elements $[26,91,94-96]$; v) BMP2 and BMP6 administration in mice increases hepcidin 
expression levels in liver and decreases plasma iron [94, 97]; vi) Conversely, administration of dorsomorphin (an ALK2, ALK3 and ALK6 inhibitor) or HJV.fc (acting as ligand trap) in mice decreases the expression of hepatic hepcidin and increases plasma iron [94, 98]; vii) Hepatic BMP6 levels are regulated by iron levels in vivo [99]. An increase in BMP6 serum levels is observed after short- and longterm iron overload [55]; viii) Iron overload phenotype observed in BMP6 null mice resembles the phenotype of HJV knock out mice [97, 100]; ix) BMP6 is produced and secreted into portal circulation by enterocytes of small intestinal villus tips in response to iron absorption [55]; x) ALK2 and ALK3 BMP type I receptors appear to be involved in mediating BMP6 signaling in liver [101].

In summary, in response to iron absorption, enterocytes produce BMP6 that is released into portal circulation. In the liver, BMP6 binds to HJV and BMP receptors type I (ALK2 and ALK6) and type II (ActRIIA and BMPRII) and via Smad1,5,8 induces hepcidin expression, which binds and downregulates ferroportin, and decreases iron plasma levels. All of these evidences suggest a model in which BMP6 is the BMP family member that controls iron homeostasis, at least in mice.

Although major advances have been made to understand the BMP/HJV/hepcidin regulatory circuit, many questions remain to be answered. Hepcidin expression is not only regulated by BMPs, but also by HFE (high iron Fe) and/or TFR2 (transferrin receptor 2), but the nature of the interplay between these molecules and the $\mathrm{BMP} / \mathrm{HJV} /$ hepcidin pathway is not known. It is also known that inflammatory cytokines, anemia and hypoxia regulate the expression levels of hepcidin, but how those pathways fit into the BMP pathway is just starting to be elucidated [101-104]. Although most evidence suggests that BMP6 produced and released by enterocytes is the master regulator of liver hepcidin levels, BMP6 is also expressed in liver cells [54]. Furthermore, siRNA induced silencing of endogenous BMP6 in HepG2 significantly reduces basal hepcidin expression [94], suggesting a role for hepatocyte derived BMP6 in the control of hepcidin expression levels. Another important issue that needs to be solved is to identify the iron sensing mechanism that leads to BMP6 upregulation in enterocytes. Recent studies have started to address one of the most relevant open questions in the field, i.e., whether or not this mechanism translates into humans $[105,106]$. Finally, it would be interesting to know whether BMP6 mutations are associated with human iron systemic diseases and whether BMP6 is the only BMP family member to play a role in iron metabolism in humans. 


\subsubsection{Glucose homeostasis}

Besides the prominent role of BMP6 in iron homeostasis, data in the literature suggest an involvement of BMP9 in the regulation of glucose homeostasis. In a screening for insulin like activity compounds, BMP9 was found to exert an anti-diabetic effect both in vitro and in vivo [107]. While this effect was clear at the hepatic level, neither effects in insulin secretion in pancreatic _ cell lines nor modulation of glucose uptake by adipocytes were observed. BMP9 effects in glucose metabolism were observed in myoblast cell lines and mainly in hepatoma cell lines. More recently, Dr. Bordin's lab found BMP9 hepatic expression to be downregulated in different models of insulin resistance in rats, while being upregulated in response to an oral glucose challenge. The most striking data were obtained by using BMP9 neutralizing antibody: injection of the BMP9 antibody in rats induced glucose intolerance and insulin resistance in fasted rats [108]. Undoubtedly, the hypothesis that BMP9 is a hypoglycemic factor as potent as insulin, in both diabetic and healthy mice, is of great interest for its potential therapeutic implications. Nonetheless, further studies are required to fully understand not only the contribution of BMP9 in the control of glucose homeostasis and the underlying mechanisms, but also the role of paracrine-endocrine-autocrine BMP9 signaling in the regulation of the metabolic pathways in the liver.

\section{BMPs in pathology}

\subsection{BMPs in liver fibrosis}

It is well established that TGF- $\beta$ has a central role in liver fibrosis $[109,110]$, but it is only in recent years when BMP involvement has been started to be addressed, raising more questions than answers up to date. Most of the knowledge we have got about the role of BMP (and in particular, BMP7) comes from kidney fibrosis studies, both in vitro and in vivo, which have shown a protective role for BMP7 [111, 112]. BMP7 inhibits TGF- $\beta$ signaling via Smads $[113,114]$ and in fact, BMP7 inhibits TGF- $\beta$ induced EMT (Epithelial to Mesenchymal transition) and even is capable of inducing the reverse phenomena, MET. Furthermore, it has been proposed that the ratio BMP7/TGF- $\beta$ is critical to decide between antifibrogenic and a

profibrogenic status. This ratio is modulated by several proteins such as LAP (Latency associated peptide), BAMBI (BMP and activin membrane-bound inhibitor), KCP (kielin/chordin-like protein) and CTGF 
(connective tissue growth factor) [112]. All these data support the notion that BMP7 has antifibrogenic properties in renal fibrosis, in part by blocking the profibrogenic activity of TGF- $\beta$.

By contrast, BMP signaling role in liver fibrosis is controversial. Some studies suggest that BMP7 has profibrogenic role in liver fibrosis. Thus, it has been shown that BMP7 expression is upregulated in cirrhotic human liver and plasma [115]. More recently, similar results have been observed in children with biliary atresia. An elevated BMP7 concentration in serum was concomitant with an impaired hepatic function and the progression of liver fibrosis. In consequence, it has been suggested that BMP7 concentration in plasma could be used as a prognostic marker for liver fibrosis [116]. It is well established that hepatic stellate cell (HSC) population plays a fundamental role in liver fibrosis $[117,118]$. BMP7 has been described to induce production of collagen and fibronectin in HSC [115]. Activated HSCs express high levels of BMP receptors and co-receptors, ALK3, ALK6, ALK2, BMPRII, ActRIIA, and Eng [115, 119, 120]. Accordingly, increase in both Smad1 expression and Smad related transcriptional activity occurs during HSC activation [121]. Id1, a well known BMP target gene has been shown to be required for HSC transdifferentiation, suggesting that BMPs are involved in this process [119]. Interestingly, in the same study, it was also shown that phosphoSmad1 and Id1 expression were elevated after bile duct ligation, further suggesting a role for Smad1/Id1 in liver fibrogenesis. In this regard, it has been reported that ALK3 and ALK6 are overexpressed in fibrotic liver [122]. All of these data suggest that BMP7 could have a profibrogenic role in liver, at least at the level of HSC transdifferentiation.

Contrarily, an antifibrogenic effect of BMP7 in liver has also been suggested in agreement with BMP7 action in renal fibrosis. Dr. Kalluri's group elegantly showed, by genetic lineage tag analysis, that hepatocytes could suffer an EMT process during liver fibrosis. In vitro TGF- $\beta$ treatment induced a complete EMT process in primary mouse hepatocytes, with all the features of this process, including the expression of FSP1 (Fibroblast specific protein 1). Importantly, TGF- $\beta$-induced EMT was blocked by recombinant BMP7 both in vitro and in vivo. Furthermore, recombinant BMP7 not only inhibited EMT but also inhibited liver fibrosis. Upon BMP7 administration they observed a decrease in fibrotic lesions and improved liver function as determined by the analysis of albumin serum levels [122]. In the same line of evidence, it has been reported that adenovirus-mediated expression of BMP7 reduces liver fibrosis in rats, but the mechanism of this effect was not determined [123]. 
BMP7 protective properties in liver injuries have been also supported by evidence suggesting that endogenous BMP7 enhances regeneration of liver mass after partial hepatectomy being therefore a physiological regulator of hepatocyte proliferation and function [5]. All these observations point at antifibrotic action of BMP7 [124]. Altogether these studies suggest a central role for BMP7 in the progress of liver fibrosis. What is the role of other BMP ligands awaits further studies but it is plausible that other members of the family could participate in liver fibrosis as it has been recently described for renal fibrosis $[125,126]$

\subsection{BMPs in liver carcinogenesis}

A growing body of evidence implicate BMPs as a target of modulation in cancer. Indeed, similar to other TGF- $\beta$ family members, such as TGF- $\beta 1$ [127], both tumor suppressor and tumor promoter activities have been described for BMPs, depending on the dose, the duration of the signal and the type and state of the target cell. Involvement of BMPs in cancer has been recently reviewed [128, 129], therefore, here only the most relevant evidences will be discussed with a major focus on the significance of BMP signaling in liver cancer.

Several tumor types, including melanoma, non small cell lung carcinoma, gastric cancer and ovarian cancer among others, have been described to overexpress members of the BMP family [130-134]. On the other hand, a loss of expression of BMP achieved by different means has also been reported in cancerous cells (reviewed in [128]. Mutations of BMPRII have been found in pancreatic tumors [135] and missense germline mutations of ALK3 are found in 20\% of Juvenile Polyposis Syndrome patients [136]. Epigenetic mechanisms, such as hypermethylation of the BMP2 promoter in gastric carcinomas, has also been reported [137]. BMPs have been associated with control of proliferation in tumor cells (both positively and negatively, extensively reviewed in [128], with promotion of migration and invasion [37, 132, 138, 139], EMT phenomena [139], metastasic processes [140-142] and also with pro-angiogenic effects [143].

The major evidences for the BMP involvement in angiogenesis come from the role of BMP receptor mutations implicated in several human vascular diseases, the most important being Hereditary hemorrhagic telangiectasia (HHT). Mutations of three genes have been described to cause HHT: Eng, a BMP coreceptor [144], ALK1, a TGF- $\beta$ type I receptor $[6,145]$, and more recently mutations of Smad4 gene, were found in a syndrome with characteristic of both HHT and the Juvenile Polyposis [146]. Other vascular 
related syndromes as pulmonary hypertension and preeclampsia show altered BMP receptors or coreceptors expression $[90,147]$. These evidences are also supported by knock out animal data. ALK1 and ENG knock out mice present an important disruption of the vascular system while other knock out animal models such as BMPRII or Smad1 null mice present milder vascular phenotypes [148, 149]. Most of BMPs (BMP2, BMP4, BMP6 and BMP7) appear to have a positive role in different aspects of the angiogenic process mainly through regulation of VEGF expression [150]. However, the role of ALK1/BMP9 system in angiogenesis is controversial. Strong data indicate that BMP9 inhibits endothelial cells proliferation and migration $[13,14]$. On the other hand, recent data support the opposite function for BMP9. Inhibition of ALK1 activity both by pharmacologic and genetic approaches inhibits angiogenesis in a mouse model of multistep tumorigenesis, therefore inhibition of the ALK1/BMP9 system impairs tumor growth and progression [151, 152]. Consistent with these data, an ALK1-Fc-fusion protein that acts as a ligand trap for BMP9 is in clinical trial, and is expected to diminish angiogenesis and proliferation of solid tumors [143, 153]. The reasons underneath the anti- versus pro-angiogenic function remain to be elucidated. Certainly, cellular state, expression of different receptors, co-receptors, and other molecules that modulate BMP signaling are likely to contribute to direct BMP9 to act as a proangiogenic or antiangiogenic factor in different cellular contexts.

As HCC is a hypervascular tumor, blocking angiogenesis to inhibit tumor growth is one of the strategies to combat this cancer [154]. In this line, efforts are being made to develop new compounds bearing antiangiogenic activity. In this line, it has been recently shown that heparan sulfate mimetic WSS25 inhibits HCC xenograft growth in nude mice. It is well known that BMPs bind to heparan sulfate on the cell surface and extracellular matrix modulating BMP signaling [155]. Qiu et al. found that WSS25 inhibits BMP4 signaling but the inhibitory effect on other BMP family members was not tested, so further mechanistic studies are needed to fully elucidate the molecular basis of its antiangiogenic function [156].

In agreement with a BMP signaling role in angiogenesis, Maegdefrau and coworkers have shown that BMP4 secreted by HCC cells increases tube formation in human microvascular endothelial cells. Interestingly, BMP4 is induced by hypoxia via a mechanism that involves Hif1 and Ets1. Furthermore, BMP4 increases the invasive properties of $\mathrm{HCC}$ cells and is required for anchorage independent growth. The authors also found that BMP4 and BMP6 are overexpressed in human HCC tissues as compared with 
normal liver tissues [157]. They also showed that BMP4 expression strongly correlates with high tumor grade [158]. The role of other BMPs in HCC has not yet been analyzed but it is tempting to speculate that other BMP ligands could also play a role in the hepatocarcinogenesis process.

\section{Applications of small molecule BMP inhibitors in human pathologies}

Experimental strategies to inhibit BMP signaling have employed recombinant endogenous antagonists, neutralizing antibodies or genetic approaches. However, in order to modulate BMP signaling in vivo with greater flexibility and decreased cost, which allows pharmacological usefulness, different laboratories have actively sought to identify small molecules with the ability to perturb BMP signaling pathway, using high throughput screening methodologies [159]. Zebra fish has proven to be a valuable model organism for this small molecule discovery. In the early zebra fish embryo, a BMP gradient is formed which results in the highest levels of signaling in the future ventral pole. On the basis of the well-characterized and essential role of BMP in dorso-ventral axis determination, $\mathrm{Yu}$ and col. hypothesized that small molecules that specifically inhibit BMP signaling might recapitulate the dorsalized axial pattern seen in the BMP pathway mutants. Using this approach, dorsomorphin (Figure 3) was reported as the first selective small molecule inhibitor of the BMP pathway, which was able to disrupt the formation of caudal and posterior structures that derive from the embryonic ventral pole [98]. Different evidences suggested that dorsomorphin binds the ATP binding site in the kinase domain of the type I BMP receptors (ALK1, ALK2, ALK3 and ALK6) [98]. Latest studies demonstrated that dorsomorphin appears to be a poor candidate for clinical development, because it is well known that inhibits AMP activated kinase (AMPK) [160] and also exhibit significant activity on several tyrosine kinase receptors [98, 161]. Nevertheless, further development of small molecule compounds with a narrower inhibition profile of BMP type I receptors is being pursued. Through a structure-activity relationship study of dorsomorphin derivatives, an optimized compound (LDN-193189, Figure 3) with higher activity and specificity on BMP type I receptors has been developed [161], although its potential effects on other protein kinases is not completely excluded [162]. In spite of their potential effects on other kinases different from the BMP pathways, these inhibitors are potentially effective for some clinical disorders. Dorsomorphin was proved to inhibit BMP-induced expression of 
hepcidin in vitro and maintained iron-hepcidin homeostasis in vivo [98] LDN-193189 attenuates anemia associated with inflammation due to its capacity to inhibit hepcidin expression [101, 163]

The use of biological compounds, such as antibodies or soluble extracellular inhibitors (traps) might allow for more specific inhibition of ALK1 activity, although caution must be taken to minimize crosstalk between different signaling pathways. The development of different biological ALK1 inhibitors for use in vivo has been reported [153]. An ALK1-Fc fusion protein (aminoacids 23-119 of mouse ALK1) was developed by Genentech to study whether ALK1 signaling controls lymphatic vessel formation [164]. Another ALK1-Fc fusion protein (AC-041) is currently in clinical development by Acceleron Pharma (human counterpart of the mouse RAP-041, aminoacids 23-119 of mouse ALK1) and has been proved to be useful for impairing tumor growth and angiogenesis [151]. Pfizer has developed a fully human monoclonal antibody against ALK1 (PF-3446962), which showed great effectiveness for anti-angiogenic therapy of cancer [165]. Notably, ALK1 blockage acts in concert with VEGF inhibitors to further reduce angiogenesis and tumor growth. Whether these tools might be useful in counteracting liver tumorigenesis has not been proved yet.

The ability to modulate BMP signaling through therapeutic tools is a promising prospect, but the roles of BMPs in physiological processes, such as bone remodeling and fracture repair cannot be ignored. However, while awaiting more conclusive data about the toxicity of long-term treatment with these compounds, short-term, intermittent or localized inhibition of BMP signaling must not be precluded.

\section{Concluding remarks}

In recent years, it has become clear that BMP family members have a role in liver physiology and pathology (a summary is recapitulated in Table I). Even so extensive work is still needed to fully clarify BMP mediated signaling, as not much is known about receptors, co-receptors, and signaling pathways that mediate BMP activities in hepatocytes and other liver cell types. A central role for BMP signaling, and particularly BMP4, in liver specification is beyond any reasonable doubt. Nonetheless, the potential contribution of other BMPs to this or other developmental stages of liver, as well as the BMP-triggered signals mediating their effects, have not yet been elucidated. Likewise, it might be fair to say that the most interesting line of research in the BMP field in the last few years opened with the discovery of the "BMP6- 
HJV-hepcidin" axis as a master regulator of iron metabolism. Certainly, there are still many unsolved matters concerning the function of this signaling axis that need to be addressed, but it has brought further attention to a potential broader role of BMPs in liver physiology. The newly discovered functions of BMPs in regulating metabolism have lead to propose that these proteins act as metabologens. Whether this emerging role of the BMPs can be extended to the liver, remains to be determined. An even more unclear but at the same time appealing scenario appears behind the role of BMPs in liver pathology. Although evidences in the literature are suggestive of a pro-tumorigenic role of BMPs in HCC, specific signaling components mediating this response still await characterization. Strikingly, both promoting and suppressing activities have been reported to be exerted by BMPs in liver fibrosis. Differential roles of the different liver cell types in the fibrotic liver and their diverse responses to BMPs may explain these apparent contradictory data. In conclusion, nowadays, we have more questions than answers about the role of BMPs in liver biology. Only a better understanding on the BMP signaling in normal healthy liver will help us to clarify the role of BMP in pathological conditions. For now, drug development to modulate BMP-dependent signaling for therapy in liver diseases remains a challenge, but the advances achieved in other tissue contexts will surely guide us to take steps in the right direction.

\section{List of abbreviations:}

ActRII: activin type II receptor

ALK: Activin receptor like kinase

AMPK: AMP activated kinase

BAMBI: BMP and activin membrane-bound inhibitor

BMP: Bone morphogenetic proteins

BMPRII: BMP type II receptor

CBP: CREB-binding protein

CTGF: Connective tissue growth factor

EMT: Epithelial to mesenchymal transition

Eng: Endoglin

ERK: Extracellular signal-regulated kinases

ES: Embryonic stem 
FoxA: Forkhead box A

FSP1: Fibroblast specific protein 1

HCC: Hepatocellular carcinoma

HFE: High iron Fe

HHT: Hereditary hemorrhagic telangiectasia

HJV: Hemojuvelin

HSC: Hepatic stellate cell

Id1: Inhibitor of DNA binding 1

JNK: c-Jun N-terminal kinases

KCP: kielin/chordin-like protein

LAP: Latency associated peptide

MAPK: Mitogen-activated protein kinases

MET: Mesenchymal to Epithelial transition

miRNA: microRNA

PI3K: Phosphatidylinositol 3-kinases

RGM: Repulsive Guidance Molecule

SBE: Smad binding element

TFR2: Transferrin receptor 2

TGF-ß: Transforming Growth Factor-beta

Xbp1: Xenopus X-box binding protein 1

\section{References}

[1] Little, S. C.; Mullins, M. C. Nat Cell Biol, 2009, 11, 637-43.

[2] Suzuki, A.; Kaneko, E.; Maeda, J.; Ueno, N. Biochem Biophys Res Commun, 1997, 232, 153-6.

[3] Valera, E.; Isaacs, M. J.; Kawakami, Y.; Izpisua Belmonte, J. C.; Choe, S. PLoS One, 2010, 5, e11167. 
[4] Sieber, C.; Kopf, J.; Hiepen, C.; Knaus, P. Cytokine Growth Factor Rev, 2009, 20, 343-55.

[5] Kiyono, K.; Suzuki, H. I.; Matsuyama, H.; Morishita, Y.; Komuro, A.; Kano, M. R.; Sugimoto, K.; Miyazono, K. Cancer Res, 2009, 69, 8844-52.

[6] Okano, J.; Shiota, G.; Matsumoto, K.; Yasui, S.; Kurimasa, A.; Hisatome, I.; Steinberg, P.; Murawaki, Y. Biochem Biophys Res Commun, 2003, 309, 298-304.

[7] Feng, X. H.; Derynck, R. Annu Rev Cell Dev Biol, 2005, 21, 659-93.

[8] Greenwald, J.; Groppe, J.; Gray, P.; Wiater, E.; Kwiatkowski, W.; Vale, W.; Choe, S. Mol Cell, 2003, 11, 605-17.

[9] Hartung, A.; Bitton-Worms, K.; Rechtman, M. M.; Wenzel, V.; Boergermann, J. H.; Hassel, S.; Henis, Y. I.; Knaus, P. Mol Cell Biol, 2006, 26, 7791-805.

[10] Lebrin, F.; Goumans, M. J.; Jonker, L.; Carvalho, R. L.; Valdimarsdottir, G.; Thorikay, M.; Mummery, C.; Arthur, H. M.; ten Dijke, P. Embo J, 2004, 23, 4018-28.

[11] Pece-Barbara, N.; Vera, S.; Kathirkamathamby, K.; Liebner, S.; Di Guglielmo, G. M.; Dejana, E.; Wrana, J. L.; Letarte, M. J Biol Chem, 2005, 280, 27800-8.

[12] Ray, B. N.; Lee, N. Y.; How, T.; Blobe, G. C. Carcinogenesis, 2010, 31, 435-41.

[13] David, L.; Mallet, C.; Mazerbourg, S.; Feige, J. J.; Bailly, S. Blood, 2007, 109, 1953-61.

[14] Scharpfenecker, M.; van Dinther, M.; Liu, Z.; van Bezooijen, R. L.; Zhao, Q.; Pukac, L.; Lowik, C. W.; ten Dijke, P. J Cell Sci, 2007, 120, 964-72.

[15] Kirkbride, K. C.; Townsend, T. A.; Bruinsma, M. W.; Barnett, J. V.; Blobe, G. C. J Biol Chem, 2008, 283, 7628-37.

[16] Lee, N. Y.; Kirkbride, K. C.; Sheu, R. D.; Blobe, G. C. Mol Biol Cell, 2009, 20, 4362-70.

[17] Lopez-Casillas, F.; Payne, H. M.; Andres, J. L.; Massague, J. J Cell Biol, 1994, 124, 557-68.

[18] Lee, J. D.; Hempel, N.; Lee, N. Y.; Blobe, G. C. Carcinogenesis, 2010, 31, 17583.

[19] You, H. J.; How, T.; Blobe, G. C. Carcinogenesis, 2009, 30, 1281-7.

[20] Corradini, E.; Babitt, J. L.; Lin, H. Y. Cytokine Growth Factor Rev, 2009, 20, 389-98.

[21] De Robertis, E. M. Mech Dev, 2009, 126, 925-41.

[22] Walsh, D. W.; Godson, C.; Brazil, D. P.; Martin, F. Trends Cell Biol, 2010, 20, 244-56.

[23] Zakin, L.; De Robertis, E. M. Curr Biol, 2010, 20, R89-92.

[24] Ishida, W.; Hamamoto, T.; Kusanagi, K.; Yagi, K.; Kawabata, M.; Takehara, K.; Sampath, T. K.; Kato, M.; Miyazono, K. J Biol Chem, 2000, 275, 6075-9.

[25] Karaulanov, E.; Knochel, W.; Niehrs, C. Embo J, 2004, 23, 844-56.

[26] Truksa, J.; Lee, P.; Beutler, E. Blood, 2009, 113, 688-95.

[27] Korchynskyi, O.; ten Dijke, P. J Biol Chem, 2002, 277, 4883-91.

[28] Gamell C, S. A., Bernard O, Rosa JL, Ventura F.

PLoS One. 2011 Jan 28;6(1):e16477., 2011, 28, E16477.

[29] Ortuno, M. J.; Ruiz-Gaspa, S.; Rodriguez-Carballo, E.; Susperregui, A. R.; Bartrons, R.; Rosa, J. L.; Ventura, F. J Biol Chem, 2010. 
[30] Ulsamer, A.; Ortuno, M. J.; Ruiz, S.; Susperregui, A. R.; Osses, N.; Rosa, J. L.; Ventura, F. J Biol Chem, 2008, 283, 3816-26.

[31] Boergermann, J. H.; Kopf, J.; Yu, P. B.; Knaus, P. Int J Biochem Cell Biol, 2010.

[32] Yang, X.; Lee, P. J.; Long, L.; Trembath, R. C.; Morrell, N. W. Am J Respir Cell Mol Biol, 2007, 37, 598-605.

[33] Chen, X.; Liao, J.; Lu, Y.; Duan, X.; Sun, W. Pathol Oncol Res., 2011, Jun 17, 257-261.

[34] Barneda-Zahonero, B.; Minano-Molina, A.; Badiola, N.; Fado, R.; Xifro, X.; Saura, C. A.; Rodriguez-Alvarez, J. Mol Biol Cell, 2009, 20, 5051-63.

[35] Gamell, C.; Osses, N.; Bartrons, R.; Ruckle, T.; Camps, M.; Rosa, J. L.; Ventura, F. J Cell Sci, 2008, 121, 3960-70.

[36] Ghosh-Choudhury, N.; Abboud, S. L.; Nishimura, R.; Celeste, A.; Mahimainathan, L.; Choudhury, G. G. J Biol Chem, 2002, 277, 33361-8.

[37] Grijelmo, C.; Rodrigue, C.; Svrcek, M.; Bruyneel, E.; Hendrix, A.; de Wever, O.; Gespach, C. Cell Signal, 2007, 19, 1722-32.

[38] Pachori, A. S.; Custer, L.; Hansen, D.; Clapp, S.; Kemppa, E.; Klingensmith, J. J Mol Cell Cardiol, 2010, 48, 1255-65.

[39] Dore, J. J.; DeWitt, J. C.; Setty, N.; Donald, M. D.; Joo, E.; Chesarone, M. A.; Birren, S. J. Dev Neurosci, 2009, 31, 473-86.

[40] Susperregui, A.; Gamell, C.; Rodríguez-Carballo, E.; Ortuño, M.; Bartrons, R.; Rosa, J.; Ventura, F. Mol Endocrinol. , 2011, Mar.

[41] Haynes, T.; Gutierrez, C.; Aycinena, J. C.; Tsonis, P. A.; Del Rio-Tsonis, K. Proc Natl Acad Sci U S A, 2007, 104, 20380-5.

[42] Foletta, V. C.; Lim, M. A.; Soosairajah, J.; Kelly, A. P.; Stanley, E. G.; Shannon, M.; He, W.; Das, S.; Massague, J.; Bernard, O. J Cell Biol, 2003, 162, 1089-98.

[43] Theriault, B. L.; Shepherd, T. G.; Mujoomdar, M. L.; Nachtigal, M. W. Carcinogenesis, 2007, 28, 1153-62.

[44] Ma, C.; Liu, Y.; He, L. Sci China C Life Sci, 2009, 52, 323-30.

[45] Wahid, F.; Shehzad, A.; Khan, T.; Kim, Y. Y. Biochim Biophys Acta, 2010, 1803, 1231-43.

[46] Samavarchi-Tehrani, P.; Golipour, A.; David, L.; Sung, H. K.; Beyer, T. A.; Datti, A.; Woltjen, K.; Nagy, A.; Wrana, J. L. Cell Stem Cell, 2010, 7, 64-77.

[47] Nakamura, T.; Mizuno, S. Proc Jpn Acad Ser B Phys Biol Sci, 2010, 86, 588-610.

[48] Lin, E. A.; Kong, L.; Bai, X. H.; Luan, Y.; Liu, C. J. J Biol Chem, 2009, 284, 11326-35.

[49] Li, Z.; Hassan, M. Q.; Volinia, S.; van Wijnen, A. J.; Stein, J. L.; Croce, C. M.; Lian, J. B.; Stein, G. S. Proc Natl Acad Sci U S A, 2008, 105, 13906-11.

[50] Yu, X.; Song, M.; Chen, J.; Zhu, G.; Zhao, G.; Wang, H.; Hunag, L. Mol Biol Rep, 2010, 37, 2423-9.

[51] Davis, B. N.; Hilyard, A. C.; Lagna, G.; Hata, A. Nature, 2008, 454, 56-61.

[52] Davis, B. N.; Hilyard, A. C.; Nguyen, P. H.; Lagna, G.; Hata, A. Mol Cell, 2010, 39, 373-84.

[53] Reinke, C. A.; Carthew, R. W. Dev Cell, 2008, 15, 174-5.

[54] Xia, Y.; Babitt, J. L.; Sidis, Y.; Chung, R. T.; Lin, H. Y. Blood, 2008, 111, 5195204. 
[55] Arndt, S.; Maegdefrau, U.; Dorn, C.; Schardt, K.; Hellerbrand, C.; Bosserhoff, A. K. Gastroenterology, 2010, 138, 372-82.

[56] Danesh, S. M.; Villasenor, A.; Chong, D.; Soukup, C.; Cleaver, O. Gene Expr Patterns, 2009, 9, 255-65.

[57] Zilberberg, L.; ten Dijke, P.; Sakai, L. Y.; Rifkin, D. B. BMC Cell Biol, 2007, 8, 41.

[58] Bidart, M.; Ricard, N.; Levet, S.; Samson, M.; Mallet, C.; David, L.; Subileau, M.; Tillet, E.; Feige, J. J.; Bailly, S. Cell Mol Life Sci, 2011.

[59] Shen, H.; Huang, G.; Hadi, M.; Choy, P.; Zhang, M.; Minuk, G. Y.; Chen, Y.; Gong, Y. Am J Physiol Gastrointest Liver Physiol, 2003, 285, G539-46.

[60] Miller, A. F.; Harvey, S. A.; Thies, R. S.; Olson, M. S. J Biol Chem, 2000, 275, 17937-45.

[61] Wandzioch, E.; Zaret, K. S. Science, 2009, 324, 1707-10.

[62] Jung, J.; Zheng, M.; Goldfarb, M.; Zaret, K. S. Science, 1999, 284, 1998-2003.

[63] Rossi, J. M.; Dunn, N. R.; Hogan, B. L.; Zaret, K. S. Genes Dev, 2001, 15, 19982009.

[64] Dudley, A. T.; Godin, R. E.; Robertson, E. J. Genes Dev, 1999, 13, 1601-13.

[65] Lyons, K. M.; Pelton, R. W.; Hogan, B. L. Genes Dev, 1989, 3, 1657-68.

[66] Somi, S.; Buffing, A. A.; Moorman, A. F.; Van Den Hoff, M. J. Anat Rec A Discov Mol Cell Evol Biol, 2004, 279, 636-51.

[67] Winnier, G.; Blessing, M.; Labosky, P. A.; Hogan, B. L. Genes Dev, 1995, 9, 2105-16.

[68] Mishina, Y.; Suzuki, A.; Ueno, N.; Behringer, R. R. Genes Dev, 1995, 9, 3027-37.

[69] Roelen, B. A.; Goumans, M. J.; van Rooijen, M. A.; Mummery, C. L. Int J Dev Biol, 1997, 41, 541-9.

[70] Eferl, R.; Sibilia, M.; Hilberg, F.; Fuchsbichler, A.; Kufferath, I.; Guertl, B.; Zenz, R.; Wagner, E. F.; Zatloukal, K. J Cell Biol, 1999, 145, 1049-61.

[71] Sosa-Pineda, B. Mol Cells, 2004, 18, 289-94.

[72] Margagliotti, S.; Clotman, F.; Pierreux, C. E.; Beaudry, J. B.; Jacquemin, P.; Rousseau, G. G.; Lemaigre, F. P. Dev Biol, 2007, 311, 579-89.

[73] Zhang, W.; Yatskievych, T. A.; Cao, X.; Antin, P. B. J Biol Chem, 2002, 277, 45435-41.

[74] Shin, D.; Shin, C. H.; Tucker, J.; Ober, E. A.; Rentzsch, F.; Poss, K. D.; Hammerschmidt, M.; Mullins, M. C.; Stainier, D. Y. Development, 2007, 134, 2041-50.

[75] Cao, Y.; Knochel, S.; Oswald, F.; Donow, C.; Zhao, H.; Knochel, W. Mech Dev, 2006, 123, 84-96.

[76] Ader, T.; Norel, R.; Levoci, L.; Rogler, L. E. Mech Dev, 2006, 123, 177-94.

[77] Rogler, C. E.; Levoci, L.; Ader, T.; Massimi, A.; Tchaikovskaya, T.; Norel, R.; Rogler, L. E. Hepatology, 2009, 50, 575-84.

[78] Mfopou, J. K.; Chen, B.; Mateizel, I.; Sermon, K.; Bouwens, L. Gastroenterology, 2010.

[79] Shiraki, N.; Umeda, K.; Sakashita, N.; Takeya, M.; Kume, K.; Kume, S. Genes Cells, 2008, 13, 731-46.

[80] Gouon-Evans, V.; Boussemart, L.; Gadue, P.; Nierhoff, D.; Koehler, C. I.; Kubo, A.; Shafritz, D. A.; Keller, G. Nat Biotechnol, 2006, 24, 1402-11. 
[81] Freathy, C.; Brown, D. G.; Roberts, R. A.; Cain, K. Hepatology, 2000, 32, 75060.

[82] Phillips, B. W.; Hentze, H.; Rust, W. L.; Chen, Q. P.; Chipperfield, H.; Tan, E. K.; Abraham, S.; Sadasivam, A.; Soong, P. L.; Wang, S. T.; Lim, R.; Sun, W.; Colman, A.; Dunn, N. R. Stem Cells Dev, 2007, 16, 561-78.

[83] Shiraki, N.; Higuchi, Y.; Harada, S.; Umeda, K.; Isagawa, T.; Aburatani, H.; Kume, K.; Kume, S. Biochem Biophys Res Commun, 2009, 381, 694-9.

[84] Erker, L.; Grompe, M. Stem Cell Res, 2007, 1, 90-102.

[85] Gennero, L.; Roos, M. A.; Sperber, K.; Denysenko, T.; Bernabei, P.; Calisti, G. F.; Papotti, M.; Cappia, S.; Pagni, R.; Aimo, G.; Mengozzi, G.; Cavallo, G.; Reguzzi, S.; Pescarmona, G. P.; Ponzetto, A. Cell Biochem Funct, 2010, 28, 17889.

[86] Roetto, A.; Papanikolaou, G.; Politou, M.; Alberti, F.; Girelli, D.; Christakis, J.; Loukopoulos, D.; Camaschella, C. Nat Genet, 2003, 33, 21-2.

[87] Nemeth, E.; Tuttle, M. S.; Powelson, J.; Vaughn, M. B.; Donovan, A.; Ward, D. M.; Ganz, T.; Kaplan, J. Science, 2004, 306, 2090-3.

[88] Nicolas, G.; Bennoun, M.; Devaux, I.; Beaumont, C.; Grandchamp, B.; Kahn, A.; Vaulont, S. Proc Natl Acad Sci US A, 2001, 98, 8780-5.

[89] Pigeon, C.; Ilyin, G.; Courselaud, B.; Leroyer, P.; Turlin, B.; Brissot, P.; Loreal, O. J Biol Chem, 2001, 276, 7811-9.

[90] Papanikolaou, G.; Samuels, M. E.; Ludwig, E. H.; MacDonald, M. L.; Franchini, P. L.; Dube, M. P.; Andres, L.; MacFarlane, J.; Sakellaropoulos, N.; Politou, M.; Nemeth, E.; Thompson, J.; Risler, J. K.; Zaborowska, C.; Babakaiff, R.; Radomski, C. C.; Pape, T. D.; Davidas, O.; Christakis, J.; Brissot, P.; Lockitch, G.; Ganz, T.; Hayden, M. R.; Goldberg, Y. P. Nat Genet, 2004, 36, 77-82.

[91] Babitt, J. L.; Huang, F. W.; Wrighting, D. M.; Xia, Y.; Sidis, Y.; Samad, T. A.; Campagna, J. A.; Chung, R. T.; Schneyer, A. L.; Woolf, C. J.; Andrews, N. C.; Lin, H. Y. Nat Genet, 2006, 38, 531-9.

[92] Malyszko, J. Kidney Blood Press Res, 2009, 32, 71-6.

[93] Zhang, A. S.; Enns, C. A. J Biol Chem, 2009, 284, 711-5.

[94] Babitt, J. L.; Huang, F. W.; Xia, Y.; Sidis, Y.; Andrews, N. C.; Lin, H. Y. J Clin Invest, 2007, 117, 1933-9.

[95] Casanovas, G.; Mleczko-Sanecka, K.; Altamura, S.; Hentze, M. W.; Muckenthaler, M. U. J Mol Med, 2009, 87, 471-80.

[96] Truksa, J.; Peng, H.; Lee, P.; Beutler, E. Proc Natl Acad Sci U S A, 2006, 103, 10289-93.

[97] Andriopoulos, B., Jr.; Corradini, E.; Xia, Y.; Faasse, S. A.; Chen, S.; Grgurevic, L.; Knutson, M. D.; Pietrangelo, A.; Vukicevic, S.; Lin, H. Y.; Babitt, J. L. Nat Genet, 2009, 41, 482-7.

[98] Yu, P. B.; Hong, C. C.; Sachidanandan, C.; Babitt, J. L.; Deng, D. Y.; Hoyng, S. A.; Lin, H. Y.; Bloch, K. D.; Peterson, R. T. Nat Chem Biol, 2008, 4, 33-41.

[99] Kautz, L.; Meynard, D.; Monnier, A.; Darnaud, V.; Bouvet, R.; Wang, R. H.; Deng, C.; Vaulont, S.; Mosser, J.; Coppin, H.; Roth, M. P. Blood, 2008, 112, 1503-9.

[100] Meynard, D.; Kautz, L.; Darnaud, V.; Canonne-Hergaux, F.; Coppin, H.; Roth, M. P. Nat Genet, 2009, 41, 478-81. 
[101] Steinbicker, A.; Sachidanandan, C.; Vonner, A.; Yusuf, R.; Deng, D.; Lai, C.; Rauwerdink, K.; Winn, J.; Saez, B.; Cook, C.; Szekely, B.; Roy, C.; Seehra, J.; Cuny, G.; Scadden, D.; Peterson, R.; Bloch, K.; Yu, P. Blood, 2011, 117, 491523.

[102] Chaston, T.; Matak, P.; Pourvali, K.; Srai, S.; McKie, A.; Sharp, P. Am J Physiol Cell Physiol. , 2011, 300, C888-95.

[103] Maes, K.; Nemeth, E.; Roodman, G.; Huston, A.; Esteve, F.; Freytes, C.; Callander, N.; Katodritou, E.; Tussing-Humphreys, L.; Rivera, S.; Vanderkerken, K.; Lichtenstein, A.; Ganz, T. Blood, 2010, 116, 3635-44.

[104] Finberg, K. E.; Whittlesey, R. L.; Fleming, M. D.; Andrews, N. C. Blood, 2010, 115, 3817-26.

[105] Bolondi, G.; Garuti, C.; Corradini, E.; Zoller, H.; Vogel, W.; Finkenstedt, A.; Babitt, J.; Lin, H.; Pietrangelo, A. Blood Cells Mol Dis. , 2011, 45, 308-12.

[106] Ryan, J.; Ryan, E.; Fabre, A.; Lawless, M.; Crowe, J. Hepatology, 2010, 52 , 1266-73.

[107] Chen, C.; Grzegorzewski, K. J.; Barash, S.; Zhao, Q.; Schneider, H.; Wang, Q.; Singh, M.; Pukac, L.; Bell, A. C.; Duan, R.; Coleman, T.; Duttaroy, A.; Cheng, S.; Hirsch, J.; Zhang, L.; Lazard, Y.; Fischer, C.; Barber, M. C.; Ma, Z. D.; Zhang, Y. Q.; Reavey, P.; Zhong, L.; Teng, B.; Sanyal, I.; Ruben, S. M.; Blondel, O.; Birse, C. E. Nat Biotechnol, 2003, 21, 294-301.

[108] Caperuto, L. C.; Anhe, G. F.; Cambiaghi, T. D.; Akamine, E. H.; do Carmo Buonfiglio, D.; Cipolla-Neto, J.; Curi, R.; Bordin, S. Endocrinology, 2008, 149, 6326-35.

[109] Matsuzaki, K. Front Biosci, 2009, 14, 2923-34.

[110] Inagaki, Y.; Okazaki, I. Gut, 2007, 56, 284-92.

[111] Nguyen, L. N.; Furuya, M. H.; Wolfraim, L. A.; Nguyen, A. P.; Holdren, M. S.; Campbell, J. S.; Knight, B.; Yeoh, G. C.; Fausto, N.; Parks, W. T. Hepatology, 2007, 45, 31-41.

[112] Weiskirchen, R.; Meurer, S. K.; Gressner, O. A.; Herrmann, J.; BorkhamKamphorst, E.; Gressner, A. M. Front Biosci, 2009, 14, 4992-5012.

[113] Wang, S.; Hirschberg, R. J Biol Chem, 2004, 279, 23200-6.

[114] Zeisberg, M.; Hanai, J.; Sugimoto, H.; Mammoto, T.; Charytan, D.; Strutz, F.; Kalluri, R. Nat Med, 2003, 9, 964-8.

[115] Tacke, F.; Gabele, E.; Bataille, F.; Schwabe, R. F.; Hellerbrand, C.; Klebl, F.; Straub, R. H.; Luedde, T.; Manns, M. P.; Trautwein, C.; Brenner, D. A.; Scholmerich, J.; Schnabl, B. Dig Dis Sci, 2007, 52, 3404-15.

[116] Chayanupatkul, M.; Honsawek, S.; Vejchapipat, P.; Chongsrisawat, V.; Poovorawan, Y. Eur J Pediatr Surg, 2009, 19, 246-50.

[117] Kordes, C.; Sawitza, I.; Haussinger, D. Biol Chem, 2009, 390, 1003-12.

[118] Roskams, T. Clin Liver Dis, 2008, 12, 853-60, ix.

[119] Wiercinska, E.; Wickert, L.; Denecke, B.; Said, H. M.; Hamzavi, J.; Gressner, A. M.; Thorikay, M.; ten Dijke, P.; Mertens, P. R.; Breitkopf, K.; Dooley, S. Hepatology, 2006, 43, 1032-41.

[120] Meurer, S.; Tihaa, L.; Borkham-Kamphorst, E.; Weiskirchen, R. Cell Signal., 2011, 23, 683-99. 
[121] Shen, H.; Fan, J.; Burczynski, F.; Minuk, G. Y.; Cattini, P.; Gong, Y. J Cell Physiol, 2007, 212, 764-70.

[122] Zeisberg, M.; Yang, C.; Martino, M.; Duncan, M. B.; Rieder, F.; Tanjore, H.; Kalluri, R. J Biol Chem, 2007, 282, 23337-47.

[123] Kinoshita, K.; Iimuro, Y.; Otogawa, K.; Saika, S.; Inagaki, Y.; Nakajima, Y.; Kawada, N.; Fujimoto, J.; Friedman, S. L.; Ikeda, K. Gut, 2007, 56, 706-14.

[124] Gressner, O. A.; Rizk, M. S.; Kovalenko, E.; Weiskirchen, R.; Gressner, A. M. J Gastroenterol Hepatol, 2008, 23, 1024-35.

[125] Dendooven, A.; van Oostrom, O.; van der Giezen, D.; Leeuwis, J.; Snijckers, C.; Joles, J.; Robertson, E.; Verhaar, M.; Nguyen, T.; Goldschmeding, R. Am J Pathol. , 2011, 178, 1069-1079.

[126] Jenkins, R.; Fraser, D. Am J Pathol., 2011, 78, 964-965.

[127] Massague, J. Cell, 2008, 134, 215-30.

[128] Singh, A.; Morris, R. J. Cytokine Growth Factor Rev, 2010, 21, 299-313.

[129] Thawani, J. P.; Wang, A. C.; Than, K. D.; Lin, C. Y.; La Marca, F.; Park, P. Neurosurgery, 2010, 66, 233-46; discussion 246.

[130] Herrera, B.; van Dinther, M.; Ten Dijke, P.; Inman, G. J. Cancer Res, 2009, 69, 9254-62.

[131] Rothhammer, T.; Wild, P. J.; Meyer, S.; Bataille, F.; Pauer, A.; KlinkhammerSchalke, M.; Hein, R.; Hofstaedter, F.; Bosserhoff, A. K. Cancer Biomark, 2007, 3, 111-7.

[132] Rothhammer, T.; Poser, I.; Soncin, F.; Bataille, F.; Moser, M.; Bosserhoff, A. K. Cancer Res, 2005, 65, 448-56.

[133] Langenfeld, E. M.; Bojnowski, J.; Perone, J.; Langenfeld, J. Ann Thorac Surg, 2005, $80,1028-32$.

[134] Aoki, M.; Ishigami, S.; Uenosono, Y.; Arigami, T.; Uchikado, Y.; Kita, Y.; Kurahara, H.; Matsumoto, M.; Ueno, S.; Natsugoe, S. Br J Cancer., 2011, 104, 714-718.

[135] Jones, S.; Zhang, X.; Parsons, D. W.; Lin, J. C.; Leary, R. J.; Angenendt, P.; Mankoo, P.; Carter, H.; Kamiyama, H.; Jimeno, A.; Hong, S. M.; Fu, B.; Lin, M. T.; Calhoun, E. S.; Kamiyama, M.; Walter, K.; Nikolskaya, T.; Nikolsky, Y.; Hartigan, J.; Smith, D. R.; Hidalgo, M.; Leach, S. D.; Klein, A. P.; Jaffee, E. M.; Goggins, M.; Maitra, A.; Iacobuzio-Donahue, C.; Eshleman, J. R.; Kern, S. E.; Hruban, R. H.; Karchin, R.; Papadopoulos, N.; Parmigiani, G.; Vogelstein, B.; Velculescu, V. E.; Kinzler, K. W. Science, 2008, 321, 1801-6.

[136] Howe, J. R.; Sayed, M. G.; Ahmed, A. F.; Ringold, J.; Larsen-Haidle, J.; Merg, A.; Mitros, F. A.; Vaccaro, C. A.; Petersen, G. M.; Giardiello, F. M.; Tinley, S. T.; Aaltonen, L. A.; Lynch, H. T. J Med Genet, 2004, 41, 484-91.

[137] Paranjpe, S.; Bowen, W. C.; Bell, A. W.; Nejak-Bowen, K.; Luo, J. H.; Michalopoulos, G. K. Hepatology, 2007, 45, 1471-7.

[138] Kang, M. H.; Kim, J. S.; Seo, J. E.; Oh, S. C.; Yoo, Y. A. Exp Cell Res, 2010, 316, 24-37.

[139] Kang, M. H.; Kang, H. N.; Kim, J. L.; Kim, J. S.; Oh, S. C.; Yoo, Y. A. Oncol Rep, 2009, 22, 525-34.

[140] Buijs, J. T.; Henriquez, N. V.; van Overveld, P. G.; van der Horst, G.; Que, I.; Schwaninger, R.; Rentsch, C.; Ten Dijke, P.; Cleton-Jansen, A. M.; Driouch, K.; 
Lidereau, R.; Bachelier, R.; Vukicevic, S.; Clezardin, P.; Papapoulos, S. E.; Cecchini, M. G.; Lowik, C. W.; van der Pluijm, G. Cancer Res, 2007, 67, 874251.

[141] Deng, H.; Makizumi, R.; Ravikumar, T. S.; Dong, H.; Yang, W.; Yang, W. L. Exp Cell Res, 2007, 313, 1033-44.

[142] Motoyama, K.; Tanaka, F.; Kosaka, Y.; Mimori, K.; Uetake, H.; Inoue, H.; Sugihara, K.; Mori, M. Ann Surg Oncol, 2008, 15, 1530-7.

[143] Pardali, E.; Goumans, M. J.; ten Dijke, P. Trends Cell Biol, 2010, 20, 556-67.

[144] McAllister, K. A.; Grogg, K. M.; Johnson, D. W.; Gallione, C. J.; Baldwin, M. A.; Jackson, C. E.; Helmbold, E. A.; Markel, D. S.; McKinnon, W. C.; Murrell, J.; et al. Nat Genet, 1994, 8, 345-51.

[145] Johnson, D. W.; Berg, J. N.; Baldwin, M. A.; Gallione, C. J.; Marondel, I.; Yoon, S. J.; Stenzel, T. T.; Speer, M.; Pericak-Vance, M. A.; Diamond, A.; Guttmacher, A. E.; Jackson, C. E.; Attisano, L.; Kucherlapati, R.; Porteous, M. E.; Marchuk, D. A. Nat Genet, 1996, 13, 189-95.

[146] Gallione, C. J.; Richards, J. A.; Letteboer, T. G.; Rushlow, D.; Prigoda, N. L.; Leedom, T. P.; Ganguly, A.; Castells, A.; Ploos van Amstel, J. K.; Westermann, C. J.; Pyeritz, R. E.; Marchuk, D. A. J Med Genet, 2006, 43, 793-7.

[147] Venkatesha, S.; Toporsian, M.; Lam, C.; Hanai, J.; Mammoto, T.; Kim, Y. M.; Bdolah, Y.; Lim, K. H.; Yuan, H. T.; Libermann, T. A.; Stillman, I. E.; Roberts, D.; D'Amore, P. A.; Epstein, F. H.; Sellke, F. W.; Romero, R.; Sukhatme, V. P.; Letarte, M.; Karumanchi, S. A. Nat Med, 2006, 12, 642-9.

[148] Rodrigues, C. M.; Ma, X.; Linehan-Stieers, C.; Fan, G.; Kren, B. T.; Steer, C. J. Cell Death Differ, 1999, 6, 842-54.

[149] Urness, L. D.; Sorensen, L. K.; Li, D. Y. Nat Genet, 2000, 26, 328-31.

[150] David, L.; Feige, J. J.; Bailly, S. Cytokine Growth Factor Rev, 2009, 20, 203-12.

[151] Cunha, S. I.; Pardali, E.; Thorikay, M.; Anderberg, C.; Hawinkels, L.; Goumans, M. J.; Seehra, J.; Heldin, C. H.; ten Dijke, P.; Pietras, K. J Exp Med, 2010, 207, 85-100, S1-5.

[152] Mitchell D, P. E., Mulivor AW, Grinberg AV, Castonguay R, Monnell TE, Solban N, Ucran JA, Pearsall RS, Underwood KW, Seehra J, Kumar R. Mol Cancer Ther, 2010, 9 379-88.

[153] Cunha, S.; Pietras, K. Blood, 2011.

[154] Sun, H. C.; Tang, Z. Y. J Cancer Res Clin Oncol, 2004, 130, 307-19.

[155] Rider, C.; Mulloy, B. Biochem J, 2010, 429, 1-12.

[156] Qiu, H.; Yang, B.; Pei, Z. C.; Zhang, Z.; Ding, K. J Biol Chem, 2010.

[157] Maegdefrau, U.; Arndt, S.; Kivorski, G.; Hellerbrand, C.; Bosserhoff, A.-K. Lab Invest, 2011.

[158] Maegdefrau, U.; Amann, T.; Winklmeier, A.; Braig, S.; Schubert, T.; Weiss, T. S.; Schardt, K.; Warnecke, C.; Hellerbrand, C.; Bosserhoff, A. K. J Pathol, 2009, 218, 520-9.

[159] Kim, S. G.; Jong, H. S.; Kim, T. Y.; Lee, J. W.; Kim, N. K.; Hong, S. H.; Bang, Y. J. Mol Biol Cell, 2004, 15, 420-34.

[160] Cai, J.; Zhao, Y.; Liu, Y.; Ye, F.; Song, Z.; Qin, H.; Meng, S.; Chen, Y.; Zhou, R.; Song, X.; Guo, Y.; Ding, M.; Deng, H. Hepatology, 2007, 45, 1229-39. 
[161] Yu, P. B.; Deng, D. Y.; Lai, C. S.; Hong, C. C.; Cuny, G. D.; Bouxsein, M. L.; Hong, D. W.; McManus, P. M.; Katagiri, T.; Sachidanandan, C.; Kamiya, N.; Fukuda, T.; Mishina, Y.; Peterson, R. T.; Bloch, K. D. Nat Med, 2008, 14, 13639.

[162] Vogt, J.; Traynor, R.; Sapkota, G. P. Cell Signal, 2011, 23, 1831-42.

[163] Theurl, I.; Schroll, A.; Sonnweber, T.; Nairz, M.; Theurl, M.; Willenbacher, W.; Eller, K.; Wolf, D.; Seifert, M.; Sun, C. C.; Babitt, J. L.; Hong, C. C.; Menhall, T.; Gearing, P.; Lin, H. Y.; Weiss, G. Blood, 2011.

[164] Niessen, K.; Zhang, G.; Ridgway, J. B.; Chen, H.; Yan, M. Blood, 2010, 115 , 1654-61.

[165] Hu-Lowe, D. D.; Chen, E.; Zhang, L.; Watson, K. D.; Mancuso, P.; Lappin, P.; Wickman, G.; Chen, J. H.; Wang, J.; Jiang, X.; Amundson, K.; Simon, R.; Erbersdobler, A.; Bergqvist, S.; Feng, Z.; Swanson, T. A.; Simmons, B. H.; Lippincott, J.; Casperson, G. F.; Levin, W. J.; Stampino, C. G.; Shalinsky, D. R.; Ferrara, K. W.; Fiedler, W.; Bertolini, F. Cancer Res, 2011, 71, 1362-73.

Figure legends

Figure 1. Canonical and non-canonical BMP signaling pathways.

Binding of BMP ligand to its membrane serine/threonine kinase receptors types I and II initiates the signaling pathway. In the canonical pathway, activated type I receptors phosphorylate R-Smads (Smads 1,5,8), which subsequently bind to the Co-Smad, Smad4. The resulting R-Smads/Co-Smad complex translocates to the nucleus, where it recruits specific transcriptional coactivators or corepressor factors to turn on or off transcription of BMP-responsive genes. BMP also activate several non-Smad pathways, 
including Rho small GTPases, NF-kB, PI3K, p38, JNK and ERK MAPKs, which modulate BMP cellular responses. Several miRNAs have recently been identified as novel downstream targets of BMP signaling mediating at least some of the BMP triggered actions.

Figure 2. Schematic representation of the proposed BMP/Hemojuvelin/Hepcidin regulatory circuit in iron metabolism. In response to high levels of iron in serum, small intestinal-enterocytes produce BMP6 and release it into portal circulation. In the liver, BMP6 binds to hemojuvelin and BMP receptors type I (ALK2 and ALK6) and type II (ActRIIA and BMPRII) and activates the Smad1/5/8 pathway, which in turn leads to an increase in hepcidin expression. Hepcidin binds to and facilitates ferroportin internalization and degradation. Ferroportin is an iron exporter, mainly expressed in duodenal enterocytes, macrophages and hepatocytes, where it controls the iron release from its body stores. Hepcidin-mediated decrease in ferroportin levels leads to decreased serum iron concentration.

Figure 3. Structures of dorsomorphin and LDN-193189, two small-molecule inhibitors of BMP signaling.

Table I. Role of different BMP family members in liver physiology and pathology 


\begin{tabular}{|l|l|c|}
\hline \multicolumn{1}{|c|}{ BMP Ligand } & \multicolumn{1}{|c|}{ Function } & References \\
\hline $\begin{array}{l}\text { BMP4 } \\
\text { (Others?) }\end{array}$ & Liver specification and liver bud formation & {$[62,72,75,76]$} \\
\hline $\begin{array}{l}\text { BMP4 } \\
\text { (BMP2?) }\end{array}$ & ESCs differentiation to hepatocyte like cells & {$[77,78]$} \\
\hline BMP6 & Control of iron homeostasis & {$[53,90,93,97]$} \\
\hline BMP7 & Enhacement of hepatocyte proliferation during regeneration & {$[52]$} \\
\hline BMP9 & Control of glucose homeostasis & {$[107,108]$} \\
\hline $\begin{array}{l}\text { BMP4; BMP6 } \\
\text { (others?) }\end{array}$ & $\begin{array}{l}\text { Increase of HCC cell migration and invasiveness } \\
{[158,159]}\end{array}$ \\
\hline $\begin{array}{l}\text { BMP7 } \\
\text { (others?) }\end{array}$ & $\begin{array}{l}\text { Liver fibrosis } \\
\text { Profibrogenic }\end{array}$ & {$[119,115,121]$} \\
\hline
\end{tabular}




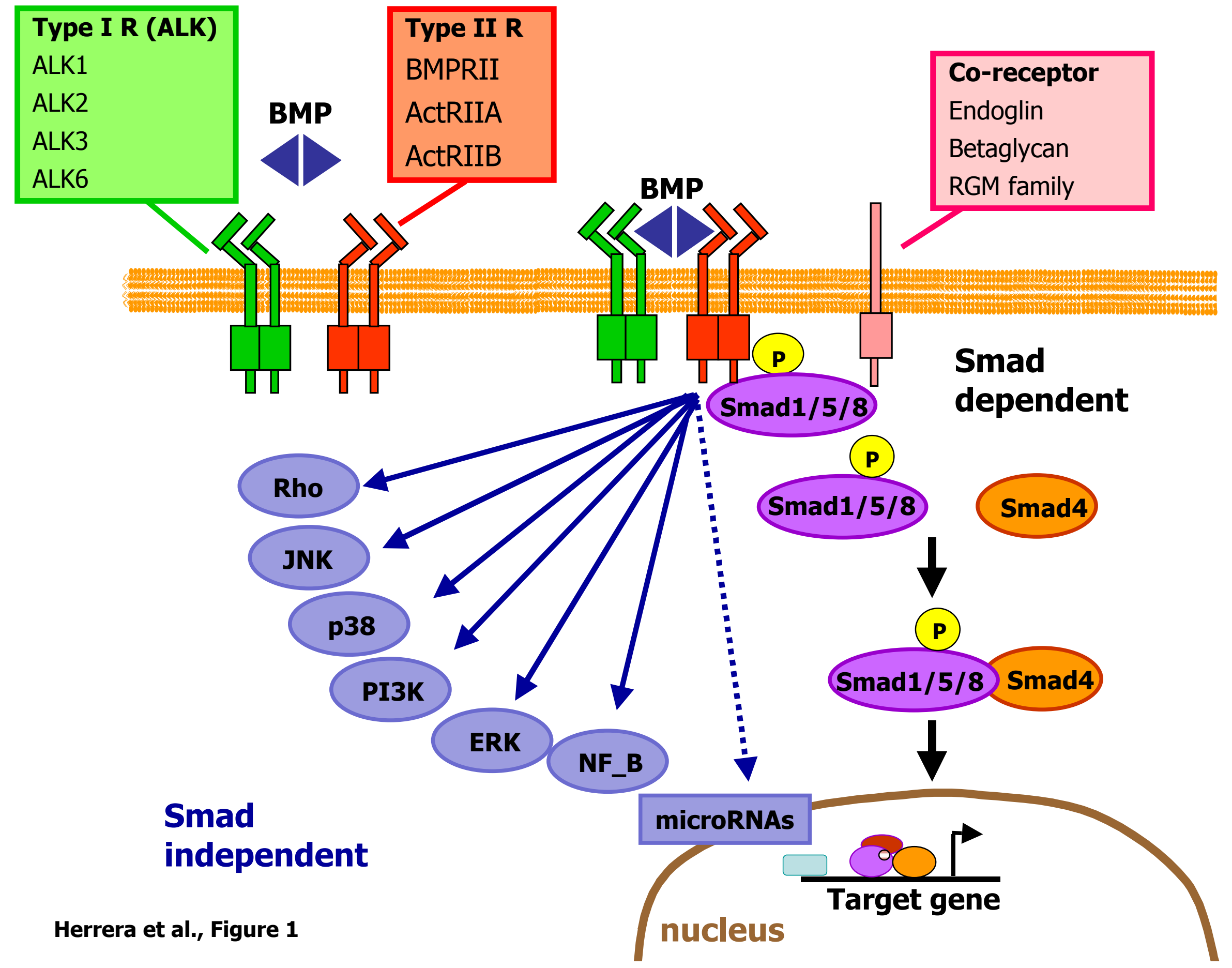




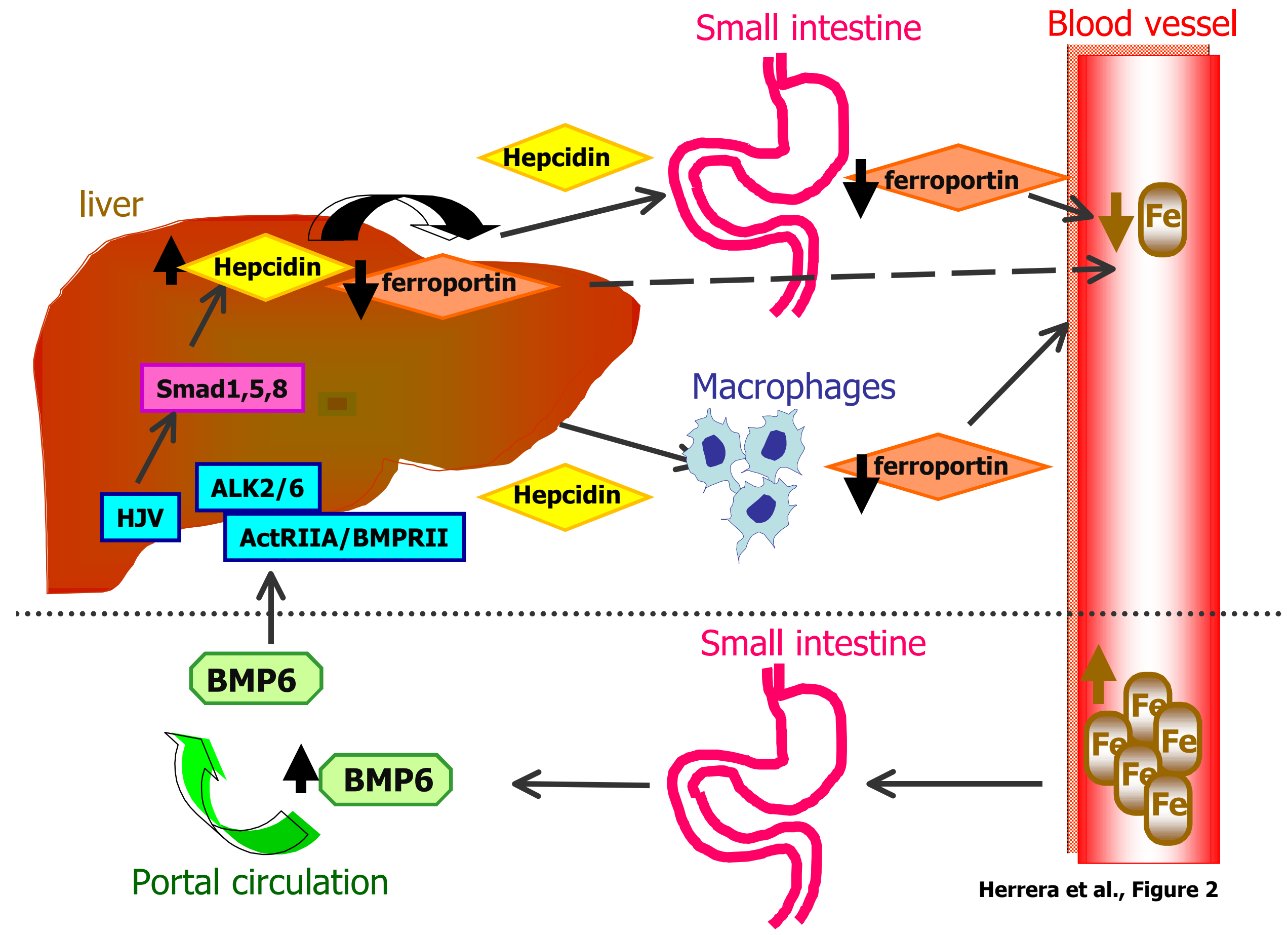




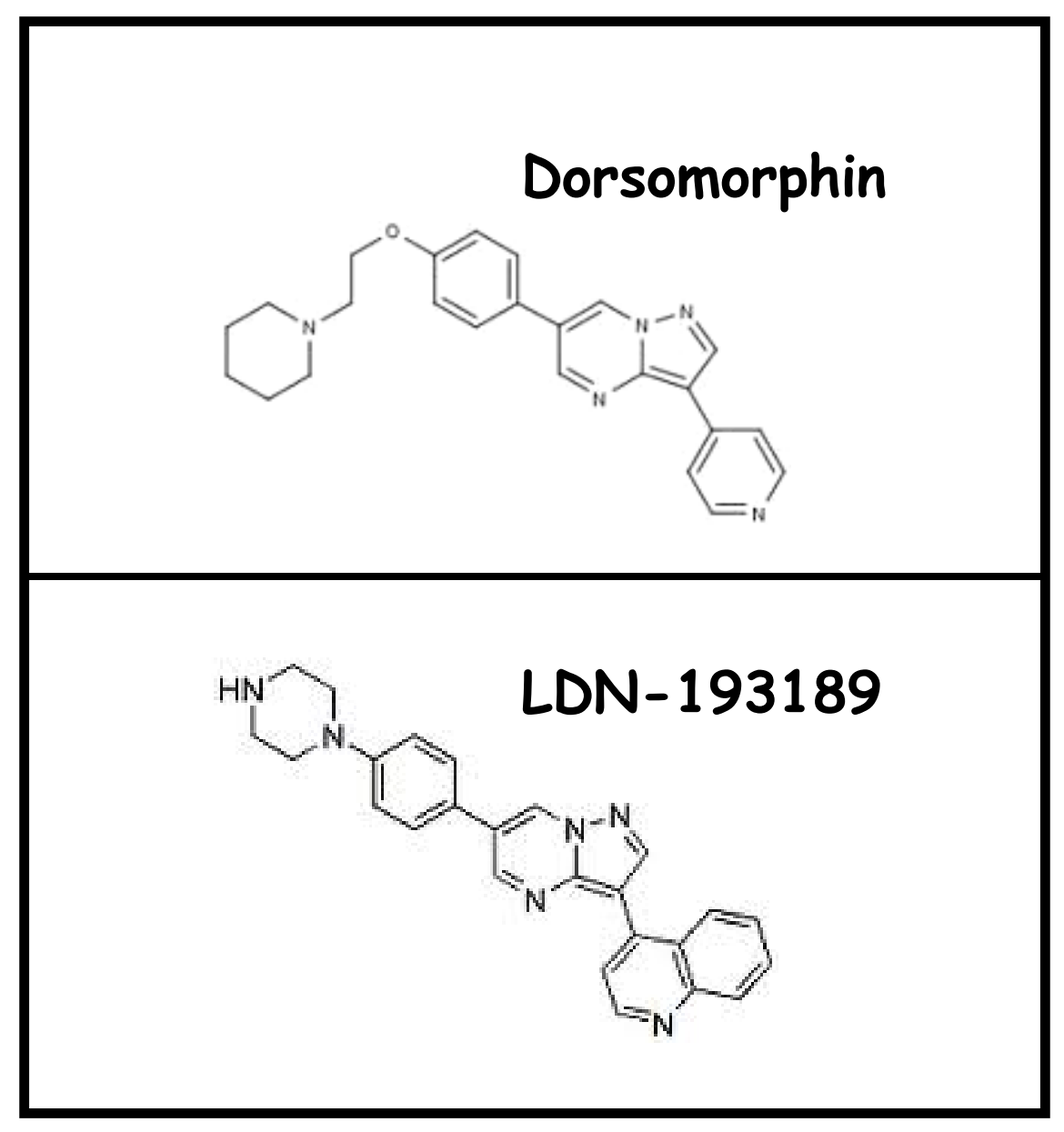

Herrera et al., Figure 3 